\title{
HUBUNGAN KEJADIAN ANEMIA PADA IBU MENYUSUI DENGAN STATUS GIZI BAYI USIA 0-6 BULAN
}

\author{
Lusi Setiyani, Aryu Candra Kusumastuti ${ }^{*}$ \\ Program Studi Ilmu Gizi Fakultas Kedokteran Universitas Diponegoro \\ Jl.Dr.Sutomo No.18, Semarang, Telp (024) 8453708, Email : gizifk@ undip.ac.id
}

\begin{abstract}
Background: Breast milk is the main nutrition for infants aged 0-6 months. Breast milk was influenced by food intake and maternal nutritional history. Anemia is one of nutrition problem caused by lack of nutrional micronutrients intake such as iron, folic acid, and vitamin B12. Maternal anemia associated with maternal performance, quality, and quantity of breast milk which will affect the nutritional status of infant.

Objective: This study was aimed to determine the relationship between the incidence of anemia on lactating mothers and nutritional status of infants aged 0-6 months.

Methods: A Cross-sectional study was conducted in 51 lactating mothers of infants age 0-6 months. Samples were selected by purposive sampling. Mother's hemoglobin levels were measured using the Cyanmethemoglobin method, infants weight were measured using Baby Scale, exclusive breastfeeding was obtained by interviews, and micronutrient intake were using obtained $3 \times 24$ hour recall method then calculated by nutrisoft. Bivariate analysis by Chi Square test.

Results: The results showed $60.78 \%$ of lactating mothers were anemic and $3.92 \%$ of infants aged 0-6 months were undernutrition. The mean of mother's hemoglobin level was $11.75 \pm 1.19$ SD and the mean z-scores of infants was $0.08 \pm 1.05$ SD. There was no significant relationship between the incidence of anemia on lactating mothers and nutritional status of infants aged 0-6 months $(p=0,75)$.

Conclusion: There was no significant relationship between the incidences of anemia on lactating mother and nutritional status of infants aged 0-6 months.
\end{abstract}

Keywords: anemia; lactating mother; and nutritional status of infants.

\begin{abstract}
ABSTRAK
Latar Belakang: Air Susu Ibu (ASI) merupakan makanan utama bagi bayi usia 0-6 bulan. ASI yang diproduksi dipengaruhi oleh asupan makan dan riwayat gizi ibu. Anemia merupakan salah satu masalah gizi yang disebabkan karena kekurangan asupan mikronutrien seperti zat besi, asam folat, dan vitamin B12. Anemia ibu akan berhubungan dengan performa ibu, kualitas dan kuantitasASI yang akan berpengaruh pada status gizi bayi.

Tujuan: Penelitian ini bertujuan untuk mengetahui hubungan kejadian anemia pada ibu menyusui dengan status gizi bayi usia 0-6 bulan.

Metode: Desain penelitian Cross Sectional dengan jumlah sampel 51 ibu menyusui yang memiliki bayi usia 0-6 bulan. Sampel ditentukan secara Purposive Sampling. Data yang diteliti meliputi kadar Hemoglobin pada ibu yang ditentukan dengan metode Cyanmethemoglobin, berat badan bayi diukur dengan Baby Scale, pemberian ASI eksklusif diketahui melalui wawancara, dan asupan mikronutrien diperoleh melalui formulir Recall $3 \times 24$ jam kemudian dihitung dengan nutrisoft. Uji yang digunakan adalah uji Chi Square.

Hasil: Hasil penelitian menunjukkan bahwa sebesar 60,78\% ibu menyusui mengalami anemia dan 3,92\% bayi usia 0-6 bulan mengalami gizi kurang. Rerata kadar hemoglobin ibu menyusui sebesar 11,75 $\pm 1,19$ SD dan rerata untuk z-score BB/U bayi sebesar 0,08 \pm 1,05 SD. Tidak ada hubungan bermakna antara kejadian anemia pada ibu menyusui dengan status gizi bayi usia 0-6 bulan $(p=0,75)$.
\end{abstract}

Simpulan: Tidak ada hubungan antara kejadian anemia pada ibu menyusui dengan status gizi bayi usia 0-6 bulan.

Kata Kunci: anemia; ibu menyusui; dan status gizi bayi.

\section{PENDAHULUAN}

Menyusui merupakan proses alamiah yang dilakukan ibu setelah mengalami masa kehamilan. Pemberian Air Susu Ibu (ASI) dianjurkan dilakukan selama 6 bulan pertama tanpa memberikan makanan tambahan (MP-ASI) kecuali obat terapi sesuai dengan program pemerintah tentang pemberian Air Susu Ibu (ASI) Eksklusif Tahun 2012. ${ }^{1,2}$
ASI mengandung zat gizi, hormon, unsur kekebalan pertumbuhan, anti alergi, serta anti inflamasi bagi tubuh bayi usia 0-6 bulan. Bayi yang mendapatkan susu formula mungkin lebih gemuk dari pada bayi yang mendapatkan ASI, tetapi belum tentu sehat. ${ }^{3}$ Menurut Riskesdas 2010, prevalensi status gizi menurut $\mathrm{BB} / \mathrm{U}$ untuk bayi usia $0-6$ bulan yaitu 4,9\% gizi buruk, $13 \%$ gizi kurang, $76,2 \%$ gizi baik, dan $5,8 \%$ gizi lebih.

${ }^{*}$ Penulis Penanggungjawab 
Sedangkan untuk prevalensi provinsi Jawa Tengah terdiri dari $3,3 \%$ gizi buruk, $12,4 \%$ gizi kurang, $78,1 \%$ gizi baik, dan $6,2 \%$ gizi lebih. ${ }^{4}$

ASI yang diproduksi dipengaruhi asupan makan dan riwayat gizi ibu. Anemia merupakan salah satu masalah gizi yang disebabkan karena kekurangan asupan zat besi yang terdapat dalam makanan sehari-hari dan adanya gangguan penyerapan zat besi oleh tubuh. ${ }^{5}$ Kejadian anemia pada ibu menyusui akan menurunkan produksi ASI, menurunkan kualitas dan kuantitas ASI. Hal tersebut berkaitan dengan kerja hormon prolaktin dan oksitosin, serta akan berpengaruh pada pemenuhan kebutuhan bayi usia 0-6 bulan. ${ }^{3}$

Angka anemia pada wanita usia subur (WUS) menurut Riskesdas 2007 mencapai 24,5 $\% .^{6}$ Pernyataan ini didukung dengan tingginya prevalensi anemia di Jawa Tengah sebesar 57,7\%, lebih tinggi dari pada prevalensi anemia WHO (2005) sebesar $41,8 \%$ dan prevalensi anemia nasional sebesar $50,9 \% .^{7,8}$ Sedangkan di kota Semarang, terjadi peningkatan prevalensi anemia pada ibu hamil dari 17,93\% pada tahun 2011 menjadi $19,14 \%$ pada tahun $2012 .{ }^{9}$

Penelitian di India tahun 2009, menyebutkan bahwa tidak ada hubungan antara tingginya angka kematian bayi dan kegagalan pencapaian pengukuran antropometri bayi pada ibu yang mengalami anemia. ${ }^{10} \mathrm{Hal}$ ini didukung dengan penelitian lain di India tahun 2007, bahwa ASI yang berasal dari ibu anemia akan berpengaruh pada kualitas. Kuantitas ASI akan berpengaruh secara signifikan apabila tidak seimbang dengan asupan yang tepat pada ibu menyusui. ${ }^{11}$ Penelitian ini bertujuan untuk mengetahui hubungan kejadian anemia pada ibu menyusui dengan status gizi bayi usia 0-6 bulan. Penelitian ini diharapkan menambah pengetahuan mengenai kejadian anemia pada ibu menyusui dengan status gizi bayi usia 0-6 bulan. Selain itu juga digunakan sebagai pertimbangan dalam pengambilan kebijakan mengenai program penanganan kejadian anemia pada ibu menyusui.

\section{METODE PENELITIAN}

Penelitian ini merupakan lingkup penelitian gizi masyarakat dengan desain Cross Sectional. Penelitian dilakukan di wilayah kerja Puskesmas Ngemplak Simongan dan Puskesmas Candi Lama. Waktu pelaksanaan penelitian ini adalah bulan Mei-Juni 2013. Jumlah sampel dalam penelitian ini sebanyak 51 ibu menyusui yang mempunyai bayi usia 0-6 bulan dan pengambilan sampel dilakukan secara purposive sampling. Kriteria inklusi dalam penelitian ini adalah bayi mendapatkan ASI eksklusif, bayi tidak memiliki kelainan bawaan, bayi dan ibu bayi tidak sedang dalam keadaan sakit selama penelitian dan 2 minggu sebelum dilaksanakan penelitian. Kriteria eksklusi dalam penelitian ini adalah subjek mengundurkan diri sebagai subjek penelitian.

Variabel independen yaitu kejadian anemia pada ibu menyusui bayi usia 0-6 bulan dan variabel dependen yaitu status gizi bayi usia 0-6 bulan. Data yang dikumpulkan dalam penelitian ini meliputi identitas ibu menyusui dan bayi usia 0-6 bulan, berat badan bayi, pemberian ASI eksklusif, dan asupan mikronutrien ibu seperti zat besi, asam folat, dan vitamin B12. Selain variabel tersebut data yang diambil antara lain pendapatan keluarga per bulan dan jumlah anggota keluarga.

Anemia pada ibu menyusui yang mempunyai bayi usia 0-6 bulan diartikan sebagai keadaan dimana kadar hemoglobin $(\mathrm{Hb})$ di dalam darah ibu lebih rendah dari nilai normal melalui pemeriksaan laboratorium. Kadar $\mathrm{Hb}$ ibu ditentukan dengan menggunakan metode cyanmethemoglobin. Kategori $\mathrm{Hb}$ dikatakan normal apabila $\geq 12 \mathrm{mg} / \mathrm{dL}$ dan termasuk anemia apabila $<12 \mathrm{mg} / \mathrm{dL}$. $^{5}$

Status gizi bayi didefinisikan sebagai keseimbangan zat gizi yang masuk ke dalam tubuh dengan kebutuhan gizi yang diperlukan tubuh dengan menggunakan indikator berat badan menurut umur $(\mathrm{BB} / \mathrm{U})$. Indikator ini dapat dilihat melalui pengukuran Z-score, dimana dikategorikan menjadi 2 yaitu gizi kurang $(<-2 \mathrm{SD})$ dan gizi baik $(\geq-2$ SD).

Asupan zat besi (Fe), asam folat, dan vitamin B12 ibu didefinisikan sebagai jumlah asupan makanan yang berkaitan dengan mikronutrien zat besi $(\mathrm{Fe})$, asam folat, dan vitamin B12 yang bersumber dari makanan yang dikonsumsi sehari-hari. Asupan zat besi, asam folat, dan vitamin B12 diukur dengan metode Recall 3x24 jam. Pengambilan data asupan zat besi $(\mathrm{Fe})$, asam folat, dan zat besi diambil setiap satu minggu sekali selama 3 minggu dan takaran sesuai dengan Ukuran Rumah Tangga (URT) kemudian dihitung dengan Nutrisoft. Asupan zat besi, asam folat, dan vitamin B12 yang didapat kemudian dibandingkan dengan Angka Kecukupan Gizi per individu per hari tahun 2004 untuk ibu menyusui dan dinyatakan dalam persen. Hasil persen kemudian dikategorikan menjadi cukup $(\geq 100 \%)$ dan kurang $(<100 \%)$. $^{12}$

Data yang diperoleh kemudian dianalisis dengan menggunakan program komputer. Analisis 
univariat dilakukan untuk mengidentifikasi data karakterstik ibu menyusui dan bayi usia 0-6 bulan. Karakteristik ibu meliputi usia, kadar $\mathrm{Hb}$, asupan zat besi (Fe), asupan asam folat, dan asupan vitamin B12. Sedangkan karakteristik bayi meliputi umur dan berat badan. Uji yang digunakan untuk mengetahui adanya hubungan kejadian anemia pada ibu menyusui dengan status gizi bayi usia 0-6 bulan adalah Chi Square .

\section{HASIL PENELITIAN}

Karakteristik Ibu Menyusui

Jumlah sampel pada penelitian ini diperoleh 51 ibu menyusui dan bayi usia 0-6 bulan yang bertempat tinggal di Kelurahan Ngemplak Simongan, Bongsari, Jomblang, dan Karanganyar Gunung. Usia ibu menyusui berkisar antara 19-32 tahun. Pendapatan keluarga tertinggi Rp 12.000.000,00 dan terendah $\mathrm{Rp}$ 500.000,00. Karakteristik ibu berdasarkan usia, pendidikan, dan pendapatan keluarga dapat dilihat pada Tabel 1 .

Tabel 1. Karakteristik Ibu Berdasarkan Usia, Pendidikan, dan Pendapatan Keluarga

\begin{tabular}{|c|c|c|}
\hline & $\mathbf{n}$ & $\%$ \\
\hline \multicolumn{3}{|l|}{ Usia Ibu } \\
\hline - 16-20 tahun & 3 & $5,9 \%$ \\
\hline $21-25$ tahun & 9 & $17,6 \%$ \\
\hline 26-30 tahun & 23 & $45,1 \%$ \\
\hline - $\quad 31-35$ tahun & 16 & $31,4 \%$ \\
\hline \multicolumn{3}{|l|}{ Pendidikan Ibu } \\
\hline$-\quad$ SD & 4 & $7,8 \%$ \\
\hline - SMP & 5 & $9,8 \%$ \\
\hline - SMA & 28 & $54,9 \%$ \\
\hline - Diploma & 4 & $7,8 \%$ \\
\hline Sarjana & 4 & $17,6 \%$ \\
\hline Tidak sekolah & 1 & $2 \%$ \\
\hline \multicolumn{3}{|l|}{ Pendapatan Keluarga } \\
\hline - $\quad<$ Rp 1.200.000,00 & 25 & $49 \%$ \\
\hline$-\quad \geq \operatorname{Rp} 1.200 .000,00$ & 26 & $51 \%$ \\
\hline
\end{tabular}

\section{Kadar Hemoglobin Ibu Menyusui}

Hasil pemeriksaan kadar hemoglobin diperoleh bahwa sebanyak 31 ibu menyusui $(60,78 \%)$ mengalami anemia. Prevalensi anemia ibu menyusui yang mempunyai bayi usia 0-6 bulan di wilayah kerja Puskesmas Ngemplak Simongan adalah 51,36\% dan Puskesmas Candi Lama adalah $85,7 \%$. Kadar hemoglobin terendah adalah 8,6 $\mathrm{mg} / \mathrm{dL}$ dan tertinggi $13,9 \mathrm{mg} / \mathrm{dL}$, dengan rerata $11,75 \pm 1,19$ SD. Kadar hemoglobin ibu menyusui dapat dilihat pada Tabel 2.

Tabel 2. Distribusi Kadar Hb di Masing-masing Wilayah Kerja Puskesmas

\begin{tabular}{lllll}
\hline \multirow{2}{*}{$\begin{array}{c}\text { Wilayah } \\
\text { Kerja } \\
\text { Puskesmas }\end{array}$} & Kelurahan & \multicolumn{2}{c}{ Kategori Hb } & \multirow{2}{*}{ Total } \\
\cline { 3 - 4 } $\begin{array}{l}\text { Ngemplak } \\
\text { Simongan }\end{array}$ & $\begin{array}{l}\text { Ngemplak } \\
\text { Simongan }\end{array}$ & $11(45,83 \%)$ & $13(54,17 \%)$ & $24(100 \%)$ \\
& Bongsari & $7(53,85 \%)$ & $6(46,15 \%)$ & $13(100 \%)$ \\
\hline \multirow{2}{*}{ Candi Lama } & Jomblang & $1(20 \%)$ & $4(80 \%)$ & $5(100 \%)$ \\
& Karanganyar & $1(11,11 \%)$ & $8(88,89 \%)$ & $9(100 \%)$ \\
\hline & Gunung & & & \\
\hline & TOTAL & $\mathbf{2 0 ( 3 9 , 2 2 \% )}$ & $\mathbf{3 1 ( 6 0 , 7 8 \% )}$ & $\mathbf{5 1 ( 1 0 0 \% )}$ \\
\hline
\end{tabular}

\begin{tabular}{|c|c|c|c|c|}
\hline $\begin{array}{l}\text { Kecukupan } \\
\text { Menyusui }\end{array}$ & Asupan & Mikronutrien & Ibu & $\begin{array}{l}\text { Asupan mikronutrien asam folat, vitamin } \\
\text { B12, dan zat besi merupakan sebagian } \\
\text { mikronutrien yang mempengaruhi terjadinya }\end{array}$ \\
\hline
\end{tabular}


kejadian anemia. Hasil penelitian ini menunjukan bahwa sebagian besar ibu menyusui mengalami defisiensi asupan asam folat, vitamin B12, dan zat besi. Distribusi frekuensi kecukupan asupan asam folat, vitamin B12, dan zat besi dapat dilihat pada Tabel 3.

Tabel 3. Distribusi Frekuensi Kecukupan Asupan Asam Folat, Vitamin B12, dan Zat Besi

\begin{tabular}{llcc}
\hline $\begin{array}{l}\text { Kecukupan asupan } \\
\text { mikronutrien }\end{array}$ & $\begin{array}{l}\text { Kategori tingkat } \\
\text { asupan }\end{array}$ & $\mathbf{n}$ & $\mathbf{\%}$ \\
\hline \multirow{2}{*}{ Asam Folat } & Cukup & 0 & 0 \\
& Kurang & 51 & 100 \\
\hline \multirow{2}{*}{ Vitamin B12 } & Cukup & 11 & 21,6 \\
& Kurang & 40 & 79,4 \\
\hline \multirow{2}{*}{ Zat Besi } & Cukup & 0 & 0 \\
& Kurang & 51 & 100 \\
\hline Total & & $\mathbf{5 1}$ & $\mathbf{1 0 0}$ \\
\hline
\end{tabular}

\section{Status Gizi Bayi Usia 0-6 Bulan}

Hasil pengukuran antropometri bayi usia 0-6 berupa z-score $(\mathrm{BB} / \mathrm{U})$ menunjukan sebanyak 2 bayi $(3,9 \%)$ mengalami Gizi kurang dengan rerata
0,08 $\pm 1,05 \mathrm{SD}$, dimana nilai Z-score terendah $-2,27$ SD dan tertinggi 2,23 SD. Distribusi frekuensi status gizi bayi menurut $\mathrm{BB} / \mathrm{U}$ dapat dilihat pada Tabel 4.

Tabel 4. Distribusi Frekuensi Status Gizi Bayi Menurut BB/U

\begin{tabular}{ccc}
\hline $\begin{array}{c}\text { Kategori Status Gizi } \\
\text { BB/U }\end{array}$ & n & \% \\
\hline Gizi baik & 49 & $96,1 \%$ \\
Gizi kurang & 2 & $3,9 \%$ \\
\hline Total & $\mathbf{5 1}$ & $\mathbf{1 0 0} \%$ \\
\hline
\end{tabular}

Hasil analisisn hubungan kadar hemoglobin dengan status gizi

Berdasarkan hasil penelitian, sebanyak 31 ibu $(60,78 \%)$ dari 51 ibu yang melakukan pemeriksaan hemoglobin mengalami anemia, dimana 1 dari ibu yang anemia memiliki bayi dengan status gizi kurang. Bayi dengan status gizi kurang juga ditemukan pada ibu dengan kadar hemoglobin normal sebanyak 1 orang. Berdasarkan analisis dengan menggunakan uji Chi square didapatkan $p>0,05$, sehingga dapat diambil kesimpulan bahwa pada penelitian ini tidak ada hubungan antara kejadian anemia pada ibu menyusui dengan status gizi bayi usia 0-6 bulan. Tabulasi silang kadar hemoglobin ibu dan status gizi bayi dapat dilihat pada Tabel 5 .

Tabel 5. Tabulasi Silang Kadar Hemoglobin Ibu dan Status Gizi Bayi

\begin{tabular}{|c|c|c|c|c|c|c|c|}
\hline & \multicolumn{4}{|c|}{ Status Gizi } & \multirow{3}{*}{ Total } & \multirow{3}{*}{$p$ value } \\
\hline & & \multicolumn{2}{|c|}{ Gizi Kurang } & \multicolumn{2}{|c|}{ Gizi Baik } & & \\
\hline & & n & $\%$ & $\mathbf{n}$ & $\%$ & & \\
\hline \multirow{3}{*}{$\begin{array}{c}\text { Kadar } \\
\text { Hb }\end{array}$} & Anemia & 1 & 3,23 & 30 & 96,77 & $31(100 \%)$ & \multirow{3}{*}{0,75} \\
\hline & Normal & 1 & 5 & 19 & 95 & $20(100 \%)$ & \\
\hline & otal & 49 & 96,08 & 2 & 392 & $51(100 \%)$ & \\
\hline
\end{tabular}

*Chi Square

\section{PEMBAHASAN}

Anemia merupakan salah satu masalah gizi yang sering terjadi pada wanita usia subur (WUS). Menurut Riskesdas 2007, prevalensi anemia pada WUS berkisar $24,5 \% .{ }^{6}$ Berdasarkan hasil penelitian terdapat $31 \mathrm{ibu}(60,78 \%)$ mengalami anemia. Hal tersebut dapat menunjukan bahwa prevalensi anemia pada ibu menyusui pada bayi usia 0-6 bulan dikategorikan tinggi karena prevalensi ini melebihi angka target dari Dinas Kesehatan Kota (DKK) Semarang sebesar $<23 \%$ dan melebihi prevalensi Jawa Tengah sebesar 57,7\%., ${ }^{9,13}$ Tingginya prevalensi anemia pada penelitian ini dipengaruhi oleh asupan ibu dan ketidakpatuhan dalam konsumsi suplemen tablet tambah darah dari tenaga kesehatan selama hamil dan masa nifas. 
Selain itu belum ada program pemerintah berkaitan dengan suplementansi tablet tambah darah untuk ibu menyusui pada enam bulan pertama.

Hasil penelitian ini menunjukan seluruh ibu menyusui (100\%) mengalami defisiensi zat besi, dengan anjuran angka kecukupan gizi (AKG) 2004 sebesar $32 \mathrm{mg}$ per hari. Ibu yang menyusui bayi $0-6$ bulan mengkonsumsi sumber zat besi dibawah standar angka kecukupan gizi (AKG) 2004 dengan rerata asupan zat besi sebesar 28,3 mg dengan asupan minimum $11,55 \mathrm{mg}$ dan maksimum 97,72mg. Zat besi merupakan komponen utama dalam pembentukan darah terutama dalam pembentukan molekul hemoglobin (hemopoiesis). Pembentukan sel darah merah dalam sumsum tulang akan terpenuhi apabila tidak ada kekurangan zat besi dan cadangan simpanan masih cukup. Apabila terjadi kekurangan zat besi secara terus menerus akan mengurangi bahkan menghabiskan cadangan zat besi yang kemudian hari akan berefek pada kejadian anemia defisiensi zat besi. ${ }^{14}$ Sumber zat besi yang mempunyai bioavailability tinggi berasal dari sumber hewani seperti daging sapi, daging ayam, telur, jerohan hati, dan ikan. ${ }^{15}$ Sebagian besar ibu menyusui kurang makan makanan sumber hewani,tetapi lebih banyak mengkonsumsi sumber nabati setiap harinya seperti tahu dan tempe. Sumber nabati mempunyai bioavailability lebih rendah dari sumber hewani, sehingga sumber zat besi dari hewani lebih cepat diserap oleh tubuh. ${ }^{15}$

Kecukupan asupan asam folat seluruh ibu menyusui (100\%) mengalami defisiensi, dengan anjuran angka kecukupan gizi (AKG) 2004 sebesar $500 \mu \mathrm{g}$ per hari. Ibu yang menyusui bayi 0 6 bulan mengkonsumsi sumber asam folat dibawah standar angka kecukupan gizi (AKG) 2004 dengan rerata asupan asam folat sebesar 27,16 $\mu \mathrm{g}$ dengan asupan minimum 7,01 $\mu \mathrm{g}$ dan maksimum 66,13 $\mu \mathrm{g}$. Asupan asam folat pada ibu menyusui tidak terpenuhi sempurna karena frekuensi ibu menyusui untuk konsumsi sayuran hijau relatif rendah. Sayuran hijau merupakan sumber asam folat. ${ }^{16}$ Sayur yang sering dikonsumsi adalah sayur sop dan sayur bayam, dimana bayam merupakan sayuran hijau yang dapat menghambat absorbsi zat besi, karena bayam mengandung oksalat. ${ }^{17}$

Kecukupan asupan vitamin B12 berbeda dengan distribusi frekuensi kecukupan zat besi dan asam folat, karena pada penelitian ini terdapat 11 ibu menyusui $(21,6 \%)$ tergolong cukup dan $40 \mathrm{ibu}$ menyusui $(79,5 \%)$ tergolong kurang untuk kategori asupan vitamin B12. Asupan vitamin B12 bisa berpengaruh pada kejadian anemia apabila ada kekurangan asupan vitamin B12. ${ }^{18}$ hal tersebut disebabkan karena vitamin B12 berfungsi untuk mengubah asam folat menjadi bentuk aktif dan apabila defisiensi akan mengalami anemia megaloblastik. ${ }^{19}$

Ketidakcukupan asupan sumber zat besi, asam folat, dan vitamin B12 pada ibu menyusui dipengaruhi oleh beberapa faktor, diantara pendapatan keluarga(daya beli), jumlah anggota keluarga, perilaku makan yang salah, dan kurangnya variasi makanan yang dikonsumsi. ${ }^{16}$ Pendapatan keluarga pada penelitian ini sebagian tergolong cukup, ${ }^{20}$ namun untuk asupan mikronutrien ibu masih belum terpenuhi. Hal tersebut sesuai dengan hasil penelitian ini bahwa asupan sumber zat besi, vitamin B12, dan asam folat yang didapat dari recall masih kurang dari AKG yang dianjurkan dan kurangnya variasi makanan yang dikonsumsi ibu menyusui dalam keseharian.

Pendidikan ibu merupakan salah satu faktor untuk menilai kepahaman dan pengetahuan ibu tentang asupan dan pemberian ASI kepada bayi. Hal tersebut sesuai dengan penelitian aeda ernawati yang menunjukan semakin tinggi pendidikan ibu maka semakin tinggi pengetahuan tentang variasi makanan. ${ }^{21}$ Variasi makanan digunakan untuk mencukupi kebutuhan ibu sendiri dan pengetahuan dalam pemberian ASI berkaitan dengan frekuensi dan durasi.

ASI merupakan makanan utama bagi bayi usia 0-6 bulan dan diberikan tanpa ada tambahan makanan atau minuman lain selain obat. ${ }^{1}$ Bayi usia 0-6 merupakan usia rawan terkena penyakit. Ketidaksesuaian frekuensi dan durasi dalam pemberian ASI akan menyebabkan tingginya angka kesakitan pada bayi dan mempengaruhi status gizi bayi. ${ }^{22}$ Hal tersebut bertentangan dengan hasil penelitian Budi Cahyadi yang menunjukan tidak ada hubungan bermakna antara pemberian ASI eksklusif dengan kejadian gizi buruk pada bayi usia 0-6 bulan, sehingga dapat disimpulkan bahwa ASI eksklusif bukan merupakan faktor resiko terjadinya gizi buruk pada bayi. ${ }^{23}$

Pada penelitian ini, terdapat 2 bayi berstatus gizi kurang yang berasal dari ibu yang mengalami anemia dan ibu yang tidak mengalami anemia. Kejadian ini terjadi karena beberapa faktor, diantaranya tidak ada kesadaran ibu untuk memberikan ASI kepada bayi secara rutin, minimal 1 jam sekali. Ketidakrutinan dalam pemberian ASI itu disebabkan dengan kesibukan ibu dengan pekerjaan rumah dan akan berpengaruh pada kelancaran pengeluaran ASI. Hormon 
oksitoksin berfungsi untuk memperlancar pengeluaran ASI. ASI yang diproduksi dipengaruhi juga oleh hormon prolaktin dan asupan makan ibu. Ibu menyusui harus meningkatkan porsi makan terutama makanan yang mengandung sumber protein. Sumber protein berfungsi membentuk jaringan baru untuk memproduksi ASI. ${ }^{24}$ Selain itu juga dibutuhkan sumber vitamin dan mineral yang digunakan untuk mendukung kuantitas dan kualitas ASI. $^{3}$

Hasil penelitian ini menunjukan bahwa tidak ada hubungan antara kejadian anemia pada ibu menyusui dengan status gizi bayi usia 0-6 bulan. Tidak adanya hubungan antara kejadian anemia pada ibu menyusui dengan status gizi bayi disebabkan karena hasil pengukuran hemoglobin paling rendah $8,6 \mathrm{mg} / \mathrm{dL}$ dengan rata-rata 11,75 $\mathrm{mg} / \mathrm{dL}$, dimana rata-rata tersebut masuk dalam kategori anemia ringan. Anemia ringan pada ibu menyusui hanya berpengaruh pada kualitas ASI, sedangkan untuk anemia berat $(<8 \mathrm{mg} / \mathrm{dL})$ akan berpengaruh pada kualitas dan kuntitas $\mathrm{ASI}^{25}$ Keadaan anemia ringan tidak mempunyai gejala yang tampak tetapi dalam jangka panjang akan berefek pada anemia berat dan akan menurunkan keadaan status gizi bayi secara bertahap sampai usia 2 tahun selama bayi masih mendapatkan ASI. $^{3}$

Status gizi bayi usia 0-6 bulan juga dapat dipengaruhi oleh lingkungan sekitar rumah yang kurang bersih dan perilaku hidup yang tidak higienis. Hal tersebut dapat menyebabkan bayi sakit pada waktu tertentu, walaupun sebagian ibu mempunyai kesadaran untuk memberikan ASI secara on demand atau rutin, minimal 1 jam sekali. Faktor tersebut ditunjukan dengan adanya penelitian yang dilakukan di kecamatan Bontoala Kota Makasar pada tahun 2007, bahwa terdapat bayi usia 0-6 bulan yang mendapatkan ASI eksklusif dari ibu sehat dan bayi tetap menderita status gizi buruk dengan faktor lingkungan yang buruk. $^{22}$

\section{KESIMPULAN}

Hasil penelitian ini dapat disimpulkan bahwa tidak ada hubungan yang signifikan antara kejadian anemia pada ibu menyusui dengan status gizi bayi usia 0-6 bulan.

\section{UCAPAN TERIMA KASIH}

Terima kasih penulis panjatkan kepada Allah SWT, atas rahmat dan kemudahan yang diberikan untuk menyelesaikan artikel ini. Terima kasih pula kepada Dosen penguji dan pembimbing atas kritik dan saran yang diberikan. Serta kepada ibu-ibu menyusui bayi usia 0-6 bulan di kelurahan Ngemplak Simongan, Bongsari, Candi Lama, dan Karangayar Gunung atas pastisipasi dan kerjasamanya dalam penelitian, tidak lupa terima kasih kepada kedua orang tua, adik, teman-teman Gizi 2009, dan teman-teman seperantauan di rumah kos'an serta semua pihak yang telah mendukung, memberikan semangat, dan memberikan bantuan dalam penelitian.

\section{DAFTAR PUSTAKA}

1. Xiaodong cai, Tessa wardlaw, and David WB. Global Trends In Exclusive Breastfeeding. International Breastfeeding Journal 2012, 7:12.

2. Kementerian Kesehatan RI. Direktorat Jenderal Bina Gizi dan Kesehatan Ibu dan Anak. Petunjuk Surveilans Gizi. Jakarta. 2012

3. Ikatan Dokter Anak Indonesia. Nutrisi Pediatrik dan Penyakit Metabolik Jilid I. Jakarta: Badan penerbid IDAI. 2011.

4. Riset Kesehatan Dasar.Jakarta : Badan Penelitian Kesehatan Kementrian Kesehatan RI.2010.

5. Arisman, MB. Gizi Dalam Daur Kehidupan. Jakarta: EGC, 2007.

6. Riset Kesehatan Dasar.Jakarta : Badan Penelitian Kesehatan Kementrian Kesehatan RI.2007.

7. WHO. Worlwide Prevalence of Anaemia 19932005. WHO Global database on anaemia CDC Atlanta. WHO Press: 2008.

8. Dinas Kesehatan Provinsi Jawa Tengah. Kumpulan Laporan Program Gizi Tahun 2009. Dinas Kesehatan Provinsi. 2009.

9. Dinas Kesehatan Kota Semarang. Kumpulan Laporan Program Gizi Tahun 2012. Dinas Kesehatan Kota Semarang. 2012.

10. Subramanian, S.V, K. Ackerson, leland ScD, Davey Smith George, MD, DSc, dkk. Association of Maternal Height With Child Mortality, Antropometric Failure, and Anemia in India. Journal American Medical Association. 2009; 301 (16): 1691-1701.

11. Shashi raj, Faridi MMA, Usha Rusia, dkk. A Prospective Study of Iron Status in Exclusively Breastfed Term Infants Up to 6 Month of Age. International Breastfeeding Journal 2008, 3:3.

12. Gibney MJ, Margetts BM, Kearney JM, Arab L. Gizi Kesehatan masyarakat (Public Health Nutrition). Jakarta: EGC. 2009.

13. Dinas Kesehatan Provinsi. Kumpulan Laporan Program Gizi Tahun 2009. Dinas Kesehatan Provinsi. 2009.

14. Adhisti, Anyndya. Hubungan Status Antropometri dan Asupan Gizi Dengan Kadar $\mathrm{Hb}$ dan Ferritin Pada Remaja Putri. Skripsi.Semarang :Badan Penerbit Universitas Diponegoro. 2011. 
15. Mahan, L.Kathleen and Stump, Sylvia Escott.. Krause's Food \& The Nutrition Care Process. Edisi 13. Philadelpia : WB Saunders Co. 2012.p 731- 738

16. Ball GFM. Vitamins in Food; Analysis, Bioavailbilty, and Stability. United States: CRC Press. 2006.p231 -305.

17. Soekirman. Ilmu gizi dan aplikasinya, untuk keluarga dan masyarakat. Jakarta: Departemen Pendidikan Nasional. 2000:102-11.

18. Howard JM, Azen C, Jacobsen DW, Green R, Carmel R. Dietary intake of cobalamin in elderly people who have abnormal serum cobalamin, methylmalonic acid and homocystein levels. Eur J Clin Nutr 1998;52:582-7.

19. Price SA, Wilson LM. Patofisiologi Konsep Klinis Proses-proses Penyakit Jilid 1. Jakarta: EGC. 2006.

20. Badan Pusat Statistik. Semarang dalam Angka. Semarang. 2012

21. Ernawati, aeda. The Associations Between Socioeconomic Factor, Hygiene, Level of Comsumptions, and Infections with the Nutritional Status of Preschool Children in Semarang District. Journal of Science UNDIP. 2003

22. Ridzal. Muh M, Veni Hadju, Rochimiawarti St. Hubungan Pola Pemberian ASI dengan Status Gizi Anak Usia 6-23 Bulan di Wilayah Pesisir Kecamatan Tallo Kota Makassar Tahun 2013. Makasar. Program Studi Ilmu Gizi FKM Universitas Hasanuddin fan Politeknik Kesehatan Makasar. 2013.

23. Cahyadi, budi. Hubungan Pemberian ASI Eksklusif dengan status Gizi Bayi Usia 6-8 Bulan di Wilayah Kelurahan Linggajaya Kecamatan Mangkubumi Kota Tasikmalaya 2012. jurnal Universitas Siliwangu Tasikmalaya 2012.

24. Bahiyatun. Buku Ajar Kebidanan Nifas Normal. Jakarta: EGC. 2009.

25. WHO, UNICEF, UNU. Iron deficiency anaemia: assessment, prevention and control, a guide for programme managers. Geneva, World Health Organization, 2001. 